\title{
Sacred space: a traditional Altai ayil
}

\author{
DOI: $10.31551 / 2410-2725-2018-4-3-387-393$
}

\section{Tadysheva Natalya Olegovna}

Candidate of Historical Sciences, Deputy Director of BNU RA «Scientific and Research Institute of Altaian Studies» n.a. S.S. Surazakov, Russian Federation, Republic of Altai, 646000, Gorno-Altaisk, 6, Sotsialisticheskaya St. E-mail: tadisheva@mail.ru

Abstract. Sacral and ordinary are the integral elements of a social organism and therefore they are a part of the mechanism regulating life of society. Representations about sacral and ordinary are very steady, giving stability to society though they also are subject to changes. The author of the article sets a task of allocation of sacral locus of the house from daily and household space. Being an object of the social character possessing communication with a cult of ancestors, fire cult, with a cult of «jaiyk» it is allocated in a sacral "auyl». It is possible to tell that such informative fullness is the most important characteristic of sacral space. Preservation of ideas of sacred «auyl» is promoted by the collective memory connected with symbolical values («own» - «stranger», «ife» - «inobytie», inter-generational communication with archaic, shaman, Burkhanist cults).

Keywords: Altays; sacral space; stability; traditional yurta; aiyl.

\section{Қасиетті кеңістік: алтайлық дәстүрлі айыл}

\section{Тадышева Наталья Олеговна}

тарих ғылымдарының кандидаты, «С.С. Суразаков атындағы алтаистика ҒЗИ» АР БҒК директорының орынбасары, Ресей Федерациясы, Алтай Республикасы, 646000, Горно-Алтайск қ, Социалистическая 6 к. E-mail: tadisheva@mail.ru

Аңдатпа. Қасиетті және қарапайым - қоғамдық ағзаның ажырамас элементтері, сондықтан олар қоғам өмірін реттейтін тетіктің бір бөлігі. Қасиетті туралы және қарапайым адамдар туралы идеялар орнықты, олар қоғамға тұрақтылық береді, сонымен қатар олар өзгеруі мүмкін. Мақала авторы күнделікті тұрмыстық кеңістікте қасиетті локалды тұрмыстық орындарды оқшаулау міндетін белгілейді. Әлеуметтік-тұрмыстық объект бола отырып, ата-бабаға табыну байланысы бар, отқа табынумен, «јайыка» ғұрпымен бірге - қасиетті «айылда» ерекшеленеді. Қасиетті кеңістіктің ең маңызды сипаты осындай ақпараттылық толықтығы деп айтуға болады. Қасиетті «айылдың» сақталуына символдық мағыналармен («жеке» - «бөтен», «болу» - «басқа», архаикалық, шаманистік, бурханистік ғұрыптармен байланыста болу) байланысты ұжымдық жады бар. Түйін сөздер: алтайлықтар; қасиетті кеңістік; тұрақтылық; дәстүрлі киіз үй; айыл.

\section{Сакральное пространство: алтайский традиционный айыл}

\section{Тадышева Наталья Олеговна}

кандидат исторических наук, заместитель директора БНУ РА «НИИ алтаистики им. С.С. Суразакова», Российская Федерация, Республика Алтай, 646000, Г. Горно-Алтайск, ул. Социалистическая 6. E-mail: tadisheva@mail.ru

Абстракт. Сакральное и обыденное - это неотъемлемые элементы социального организма, а поэтому они являются частью механизма, регулирующего жизнь общества. Представления о сакральном и обыденном являются очень устойчивыми, придающими стабильность обществу, хотя они и подвержены изменениям. Автором статьи ставится задача выделения сакральных локусов дома из повседневно-бытового пространства. Являясь объектом социально-бытового характера, обладая связью с культом предков, культом огня, культом «јайыка» - выделяется в сакральный «айыл». Можно сказать, что именно такая информативная наполненность является самой важной характеристикой сакрального пространства. Сохранению представлений о священном «айыле» способствует коллективная память, связанная с символическими значениями («свой» - «чужой», «бытие» - «инобытие», межпоколенная связь с архаическими, шаманскими, бурханистскими культами).

Ключевые слова: алтайцы; сакральное пространство; устойчивость; традиционная юрта; айыл. 


\title{
әОЖ / УДк 571.151
}

\section{Сакральное пространство: алтайский традиционный айыл ${ }^{1}$}

\author{
Н.О. Тадышева
}

Сакральное и профранное являются базовыми в любой мировоззренческой системе. Межэтническое взаимодействие приводит к конфрлитным ситуациям, обусловленным несовпадением категорий сакрального и обыденного у разных культур, ведь одна и та же вещь для одних народов является священной, а для других - обыденной. Это может вести к конфлликт, как случилось несколько лет назад в республике, когда туристы провели фотосессию обнаженной модели на фоне жертвенных ленточек кыйра в священном для коренного населения месте на перевале. Алтай, горы, перевалы, целебные источники, народ, семья, скот являются сакральными объектами для алтайцев.

Культ почитания гор существует у алтайцев с древнейших времен. Многие священные вершины обозначаются терминами «ыйык» (освященное), что зафиксировано еще в древнетюркских надписях. Статус священной горы предполагает ряд неукоснительно соблюдаемых правил: не подниматься на эту вершину без ритуальной необходимости, не охотиться на зверей и птиц на этой горе, периодически освящать ритуальными действиями. Обряд посещения целебных источников «аржанов» также регламентирован соблюдением целого комплекса ритуалов и процедур религиозного, экологического и оздоровительного характера, требует соблюдение поста, воздержания от других вредных привычек; чтобы посетить «аржан» необязательно быть больным, наоборот, следует пройти эти процедуры для поддержания жизненных сил (Уникальные 2014: 4-5).

Необходимо отметить, что пространство в восприятии традиционной культуры неоднородно и сегодня объектом исследования является сакральное пространство в традиционной юрте - «айыл». Ставится задача выделения сакральных локусов дома из повседневно-бытового пространства.

Сакральное и обыденное - это неотъемлемые элементы социального организма, а поэтому они являются частью механизма, регулирующего жизнь общества. Представления о сакральном и обыденном являются очень устойчивыми, придающими стабильность обществу, хотя они и подвержены изменениям (Кулемзин 2004: 143).

«Айыл» для алтайцев в первую очередь связан с семьей, об этом свидетельствует и устное народное творчество, и полевые материалы:

Тӥнӱктеп туткан айылга, Тйумен калык јыргазын. Катай туткан айылеа, Канча калык јыргазын. Или:

Той эдерге бириккен, Балдарыстын јаражын. Айыл тударга бириккен, Балдарыстын сӥрлӥзин.
С дымоходом построенном аиле, Множество народа пусть веселится. Совместно построенном аиле, Много народу пусть веселится².

Свадьбу, чтобы провестисоединившиеся, Молодые наши так красивы. Аил чтобы построить соединившиеся, Молодые наши такочаровательны ${ }^{3}$.

${ }^{1}$ Публикация подготовлена в рамках выполнения проекта «История и культура Великой Степи», № $Ф .0832 / П Ф Ц$.

${ }^{2}$ Полевые материалы автора (ПМА-1). Информант: Кокшинова (Арбакова) Галина Типыровна 1947 г.р., сӧӧк кӧбӧк, место рождения и проживания с. Верх-Ануй Усть-Канского района Республики Алтай. 
Так же, информанты отмечают, что нельзя строить дом для ребенка, юноши, который еще не женился. Новый айыл - это новая семья. Заранее готовясь к такому мероприятию, ты предвещаешь несчастье «ыралантран». Только женившись, мужчина получает статус «с домом и семьей» «айылду-јурттуу» ${ }^{4}$.

В этнографической литературе также зафиксирована тесная связь айыла и семьи. Так, отмечается, что старшие родственники стараются присмотреть юноше девушку из уважаемого рода, учитывают, чтобы она была из семьи, рода «јайым, јымжак эжиктӱ» род с просторной, мягкой дверью, подразумевается большой род, семья, живущая в достатке и спокойствии. Считается, что в этом случае у семьи дети будут рассудительными, благополучными. Данному роду противопоставляют «кату эжиктӱ јурт» род, семья с узкой дверью - небольшая или неполная семья, если один из членов семьи убийца, вор, злостный обманщик (Енчинов 2013: 118).

«Айыл» строят перед свадьбой, но сегодня свадьбу в большинстве проводят в доме родителей жениха и «айыл» уже построен к этому времени. В таких случаях специально для молодых «айыл» не строят. Накануне свадьбы отец или дядя жениха по материнской линии «таайы» проводят своего рода имитацию строительства аила: в шести углах они топором «јондоп јат» - строгают, как бы обновляя или сооружая новый аил. Строительство «айыла» часто имитируется, если нет «айыла» и нет возможности его поставить, «возводят айыл» из лент для проведения свадебных обрядов.

Свой «айыл» нельзя разрушать и ставить новый - тем самым укорачивается жизнь хозяина дома.

Дверь обязательно должна открываться на восток. Здесь четкое представление об оппозиции «восток» - «запад», «жизнь» - «смерть». Восход солнца, восточная сторона связаны с жизнью в этом мире; с заходом солнца, с западом - в мире предков (после смерти), все ритуальные действия совершаются по ходу солнца (кроме похоронно-поминальных). Дверь - это рубеж между чуждым миром и миром домашним, если речь идет об обычном жилище, или рубеж между миром профанным и миром сакральным, если речь идет о храме. Таким образом, «переступить порог» означает приобщиться к новому миру. Обряды, совершаемые на самом пороге, исследователь описывает как промежуточные обряды перехода (Геннеп 1999: 24). Порог - это граница между миром «своих» и «чужих». Хотелось бы обратить внимание на ритуальное действие, которое совершается при входе в юрту. Сговорив алтайскую невесту, ее привозили в «айыл» жениха. Мать жениха угощала ее молоком. Как считают исследователи, тем самым свекровь выражала свое признание будущей невестки (Тадина 1995: 85). У тувинцев после того как невеста переступает порог юрты мужа или родителей мужа ей давали также выпить молоко. Повидимому, здесь не просто жест одобрения - в данном ритуале на первый план выходит сакральность молока, представление о нем как об обереге. Войдя в «айыл», невеста, начинает приобщаться к новому дому, роду, семье и молоко может символизировать обряда очищения, который проводят для того, чтобы обезвредить опасность, которая вместе с невестой может прийти из чужого пространства.

Внутри в центре «айыла» находится очаг, таган-треножник «очок». Огонь является для многих народов стихией, которую особенно выделяли и почита-

\footnotetext{
${ }^{3}$ Полевые материалы автора (ПМА-2). Информант: Самаева Марина Анатольевна 1973 г.р., сӧӧк кӧбӧк, место рождения с. Ябоган Усть-Канского района Республики Алтай, место проживания с. Сугаш УстьКоксинского района Республики Алтай.
} ${ }^{4}$ ПMА-1. 
ли. Огонь, очаг, пространство между очагом и «чакы», где по представлениям алтайцев находится голова огня - «оттын баажы», сакрально, здесь не разрешается никому ходить. Огонь - символ новой семьи, нового дома. Благопожелание «алкыш» для молодой семьи звучит: «таш-очогы тайкылбазын, талкан-кӥли чачылбазын» - (букв. «пусть очаг не соскользнет, пусть огонь не рассыплется»). Угощение огня является просьбой благословить новую семью. При сватовстве родственники жениха, в первую очередь, поклоняются огню дома родителей невесты.

Очаг, по определению А.М. Сагалаева, - чрезвычайно емкий мифопоэтический символ. Будучи постоянным центром жилища, он определял статус освоенного пространства, он являлся тем организующим началом, вокруг которого группировалось культурное окружение (Сагалаев 1989: 173-174).

В героическом эпосе разрушение очага, потухший огонь означает несчастье в семье, в роду:

Очокто оды сооп калган,

Орыны болзо јемирилип калган.

Ончо немени кубал баскан,

Темир ӧргӧӧзи ээн калтыр.

(Эр-Самыр 2018: 32-33).
Огонь его в очаге потух

Кровать его разрушена была.

Все, что было, покрылось пеплом, Железный дворец его опустел

При исследовании культа огня в современное время прослеживается его значительное место в алтайской культуре и сегодня. Есть мнение, что душу ребенку дает Кудай. Поэтому сначала душа ребенка «суузы» «падает букв.в огонь-очаг, золу» «от-очокко, кӱлге тӥжер» -т.е. душа приходит через огонь. В связи с этим огонь считается сакральным, его держат чистым, мусор не кладут ${ }^{5}$.

При переезде в новое жилище его обязательно нужно поприветствовать «јакшылажар», выражая свою дружелюбность, нужно разжечь «новый» огонь в очаге, печке, окропить его молоком и окурить помещение горящим «арчыном» можжевельником. Таким образом, устанавливается связь, договор с оставшимися от прежних хозяев духов «элээри» новые хозяева стараются тем самым защитить себя (Енчинов 2013: 53).

По отношению к огню придерживаются особых норм поведения - нельзя размешивать огонь, направлять в него острые предметы, нельзя трогать огонь, нельзя окроплять его спиртным (водкой, красным вином, можно только использовать «аракы» - молочное вино), нельзя класть в огонь мусор, нельзя ходить между очагом и «чакы» - столб, установленный за очагом на небольшом удалении, где по представлениям алтайцев находится голова огня «отты баажы». В новолуние и когда гости пришли с гостинцами, огонь угощается «амзадар», отщипываются маленькие кусочки продуктов и кладутся в огонь.

Безусловно, нужно отметить, что во многих современных «айылах» молодых отсутствует очаг, они это объясняют тем, что на электрических и газовых плитках готовить быстро, удобно, в «айыле» нет дыма. Наблюдения показывают, при достижении среднего и выше возраста, начинают устанавливать очаг для того, чтобы проводить обряды. Видимо, это связано с переориентацией ценностей.

Очаг внутреннее пространство традиционного жилища алтайцев делит на мужскую и женскую половину. Слева мужская сторона, справа женская. Сегодня в

\footnotetext{
${ }^{5}$ Научный архив Научно-исследовательского института алтаистики имени С.С. Суразакова, дело № 119 , дневниковая запись 2017 г. Майхиева Л.М.
} 
повседневной жизни не прослеживается запрет на нахождение женщины на мужской стороне, но при проведении обрядов происходит четкое разграничение.

«Айыл» также делится в социальном плане на почетную и не почетную стороны. Пространство от двери до очага считается не почетным местом, обычно здесь садили бедняков, тех, кто не женился долго, клятвоотступников, преступников. Пространство же от очага до задней стенки - «айыла» «тӧр» наиболее почетное место, для уважаемых, почетных людей, дорогих гостей (Енчинов 2013: 57).

Исследователи начала XX в. зафиксировали, что значительное место в мировоззрении алтайцев занимали духи-охранители - «јайыки». «Ак јайык» висел в «переднем углу», «сары јайык» - направо от двери аила (Данилин 1993: $154,157)$. Хотя «сары јайык» в отличие от «ак јайык» не представлен в современной религиозной практике алтайцев, возможно, важная роль охранителя сохраняется в виде запретов о двери и пороге - нельзя играть, висеть, втыкать острые предметы и т.д. В пантеоне алтайского шаманизма «јайык» представлен как дух посредник, охранявший человека от всех несчастий и бед, именно через него приходили души всего живого, но в основная его роль заключалась в посредничестве между человеком и верхними божествами. С возникновением бурханизма значение «јайыка» актуализировалось и со временем он трансформировался в самостоятельное семейное божество.

В настоящее время в традиционном «айыле» устанавливают «јайык» напротив входа, «тӧрдӧ» на почетном месте на мужской половине. В доме, на восточной части, также напротив входа. Никто кроме человека, которому посвящен «јайык» не может прикасаться к нему «соктыртар» (букв. быть избитым, здесь будет нанесен вред здоровью). Обычно «јайык» представлен в виде изображения тотемного животного, рисунок может быть на бумаге, деревянной поверхности, способ нанесения разный, обязательно присутствует «арчын» с «кыйра»: ленточки бывают трех цветов - белого, синего и желтого.

В настоящее время обрядовые действия совершаются, главным, образом, в семейном кругу - при каждом новолунии окропляют молоком, чаем, окуривают «арчыном». Выполняет ритуал хозяин дома. Так же два раза в год во время «јажыл бӱр» (букв. зеленая листва) и «сары бӥр» (букв. осенняя листва) проводится обряд јайык кӧдйрер (букв. поднимать, здесь обряд «јайыку» (восхваление) во время новолуния, обязательно только в самые благоприятные дни - на четвертый или седьмой день новолуния. Для проведения обряда заранее готовят молоко, которое никто не пробовал, чай, «арчын», «аракы», «борсок» (мучное изделие круглой фрормы, из пресного теста, жаренное в масле). И совершают благословляющие действия - «томдогоны»: сначала окропляют огонь, затем «јайык», необходимо все приношения проводить четное количество раз. Обязательно обряд сопровождается благопожеланиями «алкыш», просят благословения Алтаю, народу, семье. Семья, проводившая обряд «бай тудар» (букв. сакральное держать, здесь придерживаться особых правил поведения): три дня из дома молоко не выносят, огонь, «арчын» никому не дают. В случаях больших несчастий в семье обряды совершаются специально приглашенным неме билер кижи.

В некоторых алтайских селах невеста в сопровождении невесток и других родственников должна, подойдя к «айылу», где проходит свадьба, обойти вокруг «айыла» некоторое число раз. В разных местах указывается разное количество - от двух до четырех, но это обязательно должно быть четное число. Как у алтайцев, так и у тувинцев и хакасов во время свадьбы обходят / объезжают три раза по солнцу юрту молодоженов. Хотя по некоторым исследовани- 
ям можно сделать вывод, что этот ритуал забывается и утеряно объяснение совершения ритуального действия (Тадышева 2011: 119; Юша 2008: 52-62).

Таким образом, сакральное пространство традиционного алтайского «айыла» актуально в современных условиях. Являясь объектом социальнобытового характера, обладая связью с культом предков, культом огня, культом «јайыка» выделяется в сакральный «айыл». Можно сказать, что именно такая информативная наполненность является самой важной характеристикой сакрального пространства. Сохранению представлений о священном «айыле» способствует коллективная память, связанная с символическими значениями («свой» - «чужой», «бытие» - «инобытие», межпоколенная связь с архаическими, шаманскими, бурханистскими культами).

\section{Әдебиеттер тізімі/ Список литературы}

1. Геннеп ван А. Обряды перехода. Систематическое изучение обрядов. - М.: Вост. лит. РАН, 1999. - 198 c.

2 Данилин А.Г. Бурханизм. - Горно-Алтайск: Изд-во «Ак Чечек», 1993. - 328 с.

3. Сагалаев А.М., Октябрьская И.В. Традиционное мировоззрение тюрков Южной Сибири. Знак и ритуал. - Новосибирск: Наука. Сиб. отд-ние, 1990. - 209 с.

4. Енчинов Э.В. Семейные ценности алтайцев: трансформация обычного права в современной культуре. - Горно-Алтайск: ИП Высоцкая Г.Г., 2013. - 226 с.

5. Кулемзин В.М. Сакральное в обыденном и обыденное в сакральном // Традиционное сознание: проблемы реконструкции. Колл. монография. - Томск: Изд-во НТЛ, 2004. - С. 140-145.

6. Уникальные объекты Горного Алтая. / Составитель Ойношев В.П. - Горно-Алтайск: ИП Колмогоров И.А., 2014. - 202 с.

7. Тадина Н.А. Алтайская свадебная обрядность (XIX-XX вв.). - Горно-Алтайск: Юч-Сюмер, 1995. - 207 c.

8. Тадышева Н.О. Влияние христианизации на семейную обрядность коренного населения Горного Алтая. - Горно-Алтайск: Горно-Алт. тип., 2011. - 176 с.

9. Тадышева Н. О. Культ јайык в традиционных представлениях алтайцев // Вестник Томского государственного университета. История. - 2013. - № 3 (23). - С. 169-171.

10. Эр-Самыр // Алтай баатырлар (Алтайские богатыри). Т. III. Серии «Памятники эпического наследия Алтая». / Подготовка, переводы текстов, примечания к алтайским текстам, комментарии к русским переводам, составление словаря выполнены М.А. Демчиновой, 3.С. Казагачевой, А.А. Конуновым, К.В. Ядановой. Предисловие М.А. Демчиновой. - Горно-Алтайск: БНУ РА «Научно-исследовательский институт алтаистики им С.С. Суразакова», 2018. - С. 10-153.

11. Юша Ж.М. Свадебная обрядность тувинцев: традиции и новации // Традиции и инновации в современном фольклоре народов Сибири. - Новосибирск, 2008. - С. 52-62.

\section{Reference}

Danilin 1993 - Danilin, AG 1993, Burhanizm, Izd-vo «Ak CHechek», Gorno-Altajsk, 328 s. (Danilin, AG 1993, Burkhanism, Izd-vo «Ak CHechek», Gorno-Altajsk, 328 p). (in Rus).

EHr-Samyr 2018 - EHr-Samyr, Altaj baatyrlar (Altajskie bogatyri). T. III. Serii «Pamyatniki ehpicheskogo naslediya Altaya», Podgotovka, perevody tekstov, primechaniya k altajskim tekstam, kommenta-rii $\mathrm{k}$ russkim perevodam, sostavlenie slovarya vypolneny MA Demchinovoj, ZS Kazagachevoj, AA Konunovym, KV YAdanovoj, BNU RA «Nauchno-issledovatel'skij institut altaistiki im S.S. Surazakova», Gorno-Altajsk, P.10-153. (EHr-Samyr, Altaj baatyrlar (Altajskie bogatyri). T. III. Serii «Pamyatniki ehpicheskogo naslediya Altaya», Training, translations, notes to the Altaic texts, comments to the Russian translation, compilation of dictionary had made MA Demchinovoj, ZS Kazagachevoj, AA Konunovym, KV YAdanovoj, BNU RA «Surazakov Scientific-research Institute of Altai studies», Gorno-Altajsk, P.10-153). (in Rus).

Enchinov 2013 - Enchinov, EhV 2013, Semejnye cennosti altajcev: transformaciya obychnogo prava $v$ sovremennoj kul'ture, IP Vysockaya G.G., Gorno-Altajsk, 226 s. (Enchinov, EhV 2013, Altaians family values: transformation of customary law in modern culture, IP Vysockaya G.G., GornoAltajsk, 226 p). (in Rus).

Gennep 1999 - Gennep van A 1999, Obryady perekhoda. Sistematicheskoe izuchenie obryadov, Vost. lit. RAN, Moscow, 198 p. (Gennep van A 1999, The Rites of passage. A systematic study of rituals Vost. lit. RAN, Moscow, 198 p). (in Rus). 
Sagalaev 1990 - Sagalaev, AM, Oktyabr'skaya, IV 1990, Tradicionnoe mirovozzrenie tyurkov YUzhnoj Sibiri. Znak i ritual, Nauka. Sib. otd-nie, Novosibirsk, 209 p. (Sagalaev, AM, Oktyabr'skaya, IV 1990, The Traditional world Outlook of Turks in South Siberia. Sign and ritual, Nauka. Sib. otd-nie, Novosibirsk, 209 p). (in Rus).

Kulemzin 2004 - Kulemzin, VM 2004, Sakral'noe v obydennom i obydennoe v sakral'nom, Tradicionnoe soznanie: problemy rekonstrukcii. Koll. Monografiya, Izd-vo NTL, Tomsk, S.140-145. (Kulemzin, VM 2004, Sacred in the ordinary and ordinary in the sacred, Traditional consciousness: problems of reconstruction, Koll. Monografiya, Izd-vo NTL, Tomsk, S.140-145). (in Rus).

Tadina 1995 - Tadina, NA 1995, Altajskaya svadebnaya obryadnost' (XIX-XX vv.), YUch-Syumer, Gorno-Altajsk, 207 p. (Tadina, NA 1995, Altai wedding ceremony (XIX-XX centuries), YUchSyumer, Gorno-Altajsk, 207 p). (in Rus).

Tadysheva 2011 - Tadysheva, NO 2011, Vliyanie hristianizacii na semejnuyu obryadnost' korennogo naseleniya Gornogo Altaya, Gorno-Alt. tip., Gorno-Altajsk, 176 p. (Tadysheva, NO 2011, The influence of Christianisation on family rituals of the indigenous population of Mountain Altai, GornoAlt. tip., Gorno-Altajsk, 176 p). (in Rus).

Tadysheva 2013 - Tadysheva, NO 2013, Kul't jajyk v tradicionnyh predstavleniyah altajcev, Vestnik Tomskogo gosudarstvennogo universiteta. Istoriya, №3(23), P.169-171. (Tadysheva, NO 2013, The cult iyc in the traditional beliefs of the altai, Bulletene of Tomsk state University. History, №3(23), P.169-171). (in Rus).

Unikal'nye ob"ekty 2014 - Unikal'nye ob"ekty Gornogo Altaya 2014, Sostavitel' Ojnoshev, VP, IP Kolmo-gorov, IA, Gorno-Altajsk, 202 p. (Unique objects of the Altai Mountains 2014, Compiled Ojnoshev, VP, IP Kolmogorov, IA, Gorno-Altajsk, 202 p). (in Rus).

YUsha 2008 - YUsha, ZhM 2008, Svadebnaya obryadnost' tuvincev: tradicii i novacii, Tradicii $i$ innovacii v sovremennom fol'klore narodov Sibiri, Novosibirsk, P.52-62. (YUsha, ZhM 2008, Wedding ceremony of Tuvans: traditions and innovations, Traditions and innovations in modern folklore of the peoples of Siberia, Novosibirsk, P.52-62). (in Rus). 